\title{
Joanna Sieńczyło-Chlabicz
}

University of Bialystok

\author{
Zofia Zawadzka
}

University of Bialystok

\section{THE PRINCIPLE OF PROPORTIONALITY AS A METHOD OF LIMITING THE PRIVACY OF PUBLIC OFFICIALS}

\begin{abstract}
It is unquestionable that people performing public functions are entitled to much narrower range of privacy protection than the so-called private persons, because of voluntarily holding a public office, the right of citizens to public information as well as the necessity of preserving transparency and openness of public life. Thus, the principle of proportionality should refer to foremost needs connected with proper functioning of public institutions, and not only to the status of people performing public functions as citizens. However, it is important to underscore that intrusion into privacy of the people of this category should be justified, every time, on grounds of a direct connection between their functioning in the sphere of private life and the function (office) performed for the state and the public good. The issue of reducing privacy of the people performing public functions requires presenting the premises of the principle of proportionality determining the restrictions in exercising the constitutional rights and liberties. The considerations in this paper will allow to analyse the solutions of the Constitutional Tribunal examining the compliance with the Constitution of statutory legal regulations which constitute an intrusion in the right to privacy of people performing public functions in view of their meeting the premises of suitability, necessity and proportionality in the strict sense in reference to the imposed limitations.
\end{abstract}

\section{Introduction}

Rights and liberties of the individual, despite being guaranteed by the Constitution of the Republic of Poland, are not of absolute nature and may be subject to restrictions. However, for these limitations to be acceptable, they should be implemented in accordance with the pattern determined by the principle of proportionality. The provision of Article 31 para 3 of the Konstytucja Rzeczypospolitej Polskiej z dnia 2 kwietnia 1997 r. (Dz. U. 
z $1997 \mathrm{Nr} 78$, poz. 483) - hereinafter referred to as the Constitution of the $\mathrm{RP}$ decides that any limitation upon the exercise of constitutional freedoms and rights may be imposed only by statute, and only when necessary in a democratic state for the protection of its security or public order, or to protect the natural environment, health or public morals, or the freedoms and rights of other persons. Such limitations shall not violate the essence of freedoms and rights.

The issue of limiting privacy of the people performing public functions requires presenting the genesis and the evolution of the principle of proportionality in the judicial decisions of the Constitutional Tribunal. It is also necessary to analyse the premises determining the restrictions in exercising the constitutional rights and liberties. The considerations in this paper will allow to analyse the solutions of the Trybunał Konstytucyjny, - hereinafter referred to as the Constitutional Tribunal examining the compliance with the Constitution of statutory legal regulations which constitute an intrusion in the right to privacy of people performing public functions in view of their meeting the premises of suitability, necessity and proportionality in the strict sense in reference to the imposed limitations.

\section{Development of the principle of proportionality in the judicial decisions of the Constitutional Tribunal in historical perspective}

The process of forming the principle of proportionality, which, in its present shape, is expressed in Article 31 para 3 of the as the Constitution of the RP goes back many years ago and results from the gradual process of becoming increasingly precise in the judicial decisions of the Constitutional Tribunal. Forming of the principle of proportionality by the Constitutional Tribunal was a process which consisted of many decisions forming one by one particular elements of this principle. (Stępkowski, 2010, pp. 327-348; Dylewska, 2001, p. 47 and next; Zakolska, 2008, pp. 32-68). The decisions of the Constitutional Tribunal were made in view of questioning the constitutionality of the regulations included in acts of law on various individual rights and liberties. The argumentation in the statements of reasons of the decisions is transferable onto considerations on the constitutionality of other liberties and rights in the case of any doubts occurring in this field, including the right to privacy.

From the historical point of view, neither the Konstytucja Polskiej Rzeczypospolitej Ludowej (Dz. U. z 1952 Nr 33, poz. 232 z późn. zm.) nor the 
The Principle of Proportionality as a Method of Limiting the Privacy...

subsequent amendments or the ustawa konstytucyjna z dnia 17 października 1992 r. o wzajemnych stosunkach między władzą ustawodawczą i wykonawczą Rzeczypospolitej Polskiej oraz o samorządzie terytorialnym (Dz. U. $1992 \mathrm{Nr} 84$ poz. 426 z późn. zm.) contained a provision providing for a possibility of limiting the guaranteed rights and liberties. The principle of proportionality was expressed directly in the provisions of law only when the Constitution of the RP of 2 April 1997 entered into effect. The derivation of the possibilities of limitations and their premises is a contribution of the Constitutional Tribunal's decisions, which formed the so-called principle of proportionality, also referred to as the prohibition of excessive interference with a right (Wojtyczek, 2002, p. 679), before the Constitution of the RP of 1997 entered into effect.

The principle of proportionality, due to the lack of separate regulations, was derived by the Constitutional Tribunal from the principle of democratic state ruled by law (Zakolska, 2008, p. 32; Walaszek-Pyzioł, 1995, p. 5) as well as from the principle of citizens' trust in the state, which was based on comparative law research as well as judicial decisions and doctrines of western states. (Zakolska, 2008, p. 37). Its development in the form it currently functions was inspired by the German doctrine and judicial decisions. (Wojtyczek, 2002, p. 678; Stępkowski, 2010, p. 189-209). It is important that the very term "principle of proportionality" is derived from German law. This principle has its source in judicial decisions of the Prussian Higher Administrative Court (Oberverwaltungsgericht) of the late 19th century, (Wojtyczek 2002, p. 678; Łabno, 2002, p. 704; Dylewska 2001, p. 46) which developed the so-called principle of proportionality (Grundsatz der Verhältnismäßigkeit) or, in other words, the prohibition of excessive interference with a right (Übermaßverbot) and its three components. In German law the structure of restrictions of individual liberties and rights is based on the relation between the means and the end. It commands that between the aim of the introduced legal regulation and the means resulting therefrom, which aim at achieving this goal be an appropriate proportion, (Zakolska, 2008, p. 10) i.e. the means be adjusted to the ends which the legislator wants to achieve. The structure of the principle of proportionality is a product of the doctrine and judicial decisions for it was not expressed explicitly in the provisions of law. In accordance with the German doctrine of constitutional law the principle of proportionality consists of three elements:

1) the requirement of utility, suitability (Gebot der Geeignetheit),

2) the requirement of necessity, indispensability or the mildest intrusion (Gebot der Erforderlichkeit) and 
3) the requirement of proportionality in the strict sense, also referred to as the prohibition of excessive intrusion (Gebot der Verhältnismäßigkeit im engeren Sinne/Angemessenheit / Zumutbarkeit). (Stelzer, 1991, p. 96; Martins, 2001, p. 120; Banaszak, 2009, p. 181; Wojtyczek, 2002, p. 670; Zakolska, 2008, p. 25; Walaszek-Pyziol, 1995, pp. 15-16).

The first stage of the process of specifying the principle of proportionality was that the Polish Constitutional Tribunal noticed that the nature of constitutional rights and liberties is not absolute and recognising the acceptability of their limitations. This position was presented by the Constitutional Tribunal, for example, in orzeczenie Trybunału Konstytucyjnego z dnia 26 stycznia $1993 \mathrm{r}$. (U 10/92). The Tribunal stated that this freedom is of no absolute nature. It demonstrated that situations where it will remain in conflict with other principles and constitutional norms and, therefore, its restrictions are acceptable. Moreover, it underscored that the limitations introduced cannot lead to creating "empty norms", cannot go so far that the essence of a particular law was cancelled. Thus, the Constitutional Tribunal noticed the situation of conflict between competing principles and formed an origin of the principle subsequently named by the doctrine and judicial decisions a prohibition of infringing the essence of a particular liberty and right. It also emphasised a very important aspect of possibility of restrictions which must be assumed every time balancing the weight of the right or the liberty subject to limitations and the weight of the right or the liberty justifying this limitation. Failure to comply proportionality in this matter or adopting unnecessarily excessive limitation results in unconstitutionality of the legal regulation.

The next stage of the process of specifying the principle of proportionality was forming the conditions of acceptability of the restrictions of constitutional rights and liberties because of other protected rights and liberties. As for acceptability of limiting the freedom of speech the Constitutional Tribunal repeated in uchwała Trybunału Konstytucyjnego z dnia 2 marca $1994 \mathrm{r}$. that this principle is not absolute and can be limited even in the Constitution itself because of other rights and liberties protected in the legal system. (W3/93). Analysing the premises of acceptability of limitations the Constitutional Tribunal recognised meeting three necessary conditions, which formed as follows:

1) statutory limitations of rights or liberties are acceptable only when they are explicitly provided for in the constitutional provisions or the need for limitations results from the necessity for mutual harmonising the particular principle with other principles, norms and constitutional values; 
The Principle of Proportionality as a Method of Limiting the Privacy...

2) statutory limitations may be introduced only to a necessary extent and must be treated as exceptions, and their existence must always result from clearly formed statutory provisions;

3) neither particular limitations nor their sum cannot infringe the essence of the particular principle.

The conditions set by the Tribunal, mentioned above as 2 and 3, were defined in the doctrine as the requirement of necessity and the requirement of proportionality in the strict sense. In turn, all the other conditions formed by the Tribunal were repeated, only in a different order, in orzeczenie Trybunału Konstytucyjnego z dnia 7 czerwca 1994 r. (K 17/93). The Tribunal repeated the opinion that constitutional liberties and rights may be limited on condition that: first, the limitation does not infringe the essence of the particular principle; second, the limitation is clearly allowed in other constitutional provisions or it is necessary to harmonise mutually constitutional values and, third, the limitation may be imposed by an act of law only, to a necessary extent and as an exception.

The Constitutional Tribunal for the first time explicitly referred to the principle of prohibition of excessive interference with a right, now known as the principle of proportionality, in orzeczenie Trybunału Konstytucyjnego z dnia 24 czerwca $1997 \mathrm{r}$. (K 17/93; K 21/96). It pointed out that this principle makes an injunction directed to the state that the intrusion into the sphere of individual rights were reduced to necessary cases only and to a necessary degree only. The principle of prohibition of excessive interference with a right, in the opinion of the Constitutional Tribunal manifests itself in the fact that the legislator cannot impose such limitations that exceed a certain degree of onerousness, in particular if they infringe the proportion between the degree of individual right infringement and the weight of the public interest, which is expected to be protected in this way. Ipso facto the function of the principle of proportionality is the protection of individual rights and liberties. (K 12/93). In order to facilitate an assessment if the limitation meets the requirements of proportionality the Constitutional Tribunal posed three questions:

1) Is the introduced legislative regulation able to lead to the results intended by this regulation?

2) Is this regulation necessary to protect public interest with which it is connected?

3) Do the effects of the introduced regulation remain in proportion to the burdens imposed upon the citizen? (K 11/94; K 10/95; K 33/98; K 19/01).

Affirmative answers to all three questions is the evidence of the con- 
stitutionality of the regulation and of preserving the proportionality of the limitation imposed. The aforementioned questions are conveyed in the views of the doctrine in form of four specific questions:

1) Does the introduced statutory regulation serve its purpose and is it necessary to shape a legal order in a certain sphere of relations?

2) Is the objective of this regulation, intended by the legislator, possible to achieve without infringing basic standards of law expressing the essence of the rights which it concerns?

3) Is this regulation necessary to protect the public interest with which it is connected?

4) Do the effects of the introduced regulation remain in proportion to the burdens imposed by it upon the citizen? (Oniszczuk, 2000, p. 264; Banaszak, 2009, p. 181-182; Wyrzykowski, 1998, p. 51).

Independently from the aforesaid questions representatives of the doctrine point at the necessity of meeting two additional requirements: first, the aim, because of which the limitation occurs, should be the public good and, second, the form of the limitation of a given individual law should be expressed in form of accurate injunctions and prohibitions. (Walaszek-Pyziol, 1995, pp. 15-16; Dylewska, 2001, pp. 46-47).

To sum up, despite the different approaches in the judicial decisions of the Constitutional Tribunal and the doctrine, the above questions contain three requirements constituting elements of the principle of proportionality: the requirement of suitability, necessity (indispensability) and proportionality in the strict sense. A similar solution is adopted in the German doctrine. ${ }^{1}$ (Łabno, 2002, pp. 705).

In the subsequent decisions of the Constitutional Tribunal, however before the Constitution of the RP entered into effect, the principle of proportionality constituted a model of constitutional control mentioned even in the sentences themselves. (K12/93; K 10/95). The Constitutional Tribunal referred to the infringement of the principle of citizens' trust in the state and its laws through excessive intrusion into particular rights and liberties, which was against the principle of democratic state ruled by law. (K 12/93). In turn, the decision of the Constitutional Tribunal of 17 October 1995 found non-compliance of the regulation assessed with the provisions of the Constitution. The Tribunal decided that without a necessary reason justified with an important public interest, it reduced the rights excessively, thereby violating, inter alia, the principle of proportionality.

Along with the Constitution of the RP of 2 April 1997 entering into effect Article 2 of the Constitution of the RP and the principle of democratic state ruled by law were less and less frequently used as a sole pattern of 
The Principle of Proportionality as a Method of Limiting the Privacy...

constitutionality control in the decisions of the Constitutional Tribunal. The independent pattern for deciding on unconstitutionality of the questioned regulations is Article 31 para 3 of the Constitution of the $\mathrm{RP}$ expressing the principle of proportionality and the prohibition of excessive interference with a right. (P 2/98; Stępkowski, 2010, pp. 355-360; Wojtyczek, 2002, p. 680; Łabno, 2002, p. 705).

\section{The range of the protection of privacy of people performing public functions in the judicial decisions of the Constitutional Tribunal}

The Constitution of the RP does not include the notion of privacy, and only Article 47 contains the guarantee of legal protection of private life. It seems that the notion of privacy should be understood and interpreted alike in various branches of law, and the superior position of the constitutional norm makes a basis for distinguishing certain common elements. (Safjan, 2002, p. 232). Currently, the dominant element within the broad sense of privacy is information autonomy. It is just this element of privacy which is most strongly emphasised in the judicial decisions of the Constitutional Tribunal. (Sieńczyło-Chlabicz, 2006, p. 102).

According to the position of the Constitutional Tribunal expressed in its judicial decisions: "the constitutional right to privacy should be understood foremost as a right to keep in secret information about the individual's private life". (K 21/96). Privacy refers to the protection of information about a particular person, guarantees a certain state of independence within which the individual may decide on the scope and the range of sharing and communicating information about his/her life to other people. (K 21/96; U 6/97). Also the state of health and material situation are part of the circle of privacy. By principle this information is not for spreading and it is the eligible and interested person who decides to whom he/she wants to provide the information. (Banaszak, 2009, p. 246).

The Constitutional Tribunal expressed an opinion that it is not possible to present precisely and to enumerate the components of the right to privacy. (K 1/98). However in the content of subsequent decisions of the Constitutional Tribunal we can find an aspiration to specify this term. According to the Constitutional Tribunal the right to privacy resulting from Article 47 of the Constitution of the RP guarantees protection of family life in such aspects as stability of the family and marriage as well as protects family ties in both personal and economic sense. In its considerations in the 


\section{Joanna Sieńczyło-Chlabicz, Zofia Zawadzka}

decision of 13 July 2004, the Constitutional Tribunal presented a position that frequently even revelation of family relations or their lack may in certain circumstances lead to the violation of privacy, especially in relation to the information about children born out of wedlock or half-siblings. Moreover, the necessity of informing about such situations as purchasing a flat or taking a job in another town may indirectly give away the family situation, life plans, and in particular reveal important circumstances such as the intention of starting a family, its enlargement, actual separation or divorce. ${ }^{2}$

The Constitutional Tribunal also combined the right to privacy with the guarantees of personal information protection included in Article 51 of the Constitution of the RP. In accordance with the judicial decisions of the Constitutional Tribunal the sphere of the individual's private life includes undoubtedly information on the state of health and the type of illness. (U 5/97; Oniszczuk, 2004, pp. 398-399). The Constitutional Tribunal drew attention to the particular protection of the information on the state of health as well as the sphere of intimacy, including sexual life in the decision of 20 March 2006. The Tribunal underscored that such data cannot be subject to the right to information, and citizens cannot demand their revelation in reference to the people performing public functions. (K 17/05).

On the basis of the judicial decisions of the Constitutional Tribunal we can draw a conclusion that the Tribunal frequently considers the right to privacy in connection with Article 51 of the Constitution of the Republic of Poland, which grants the statutory level to the right to the individual's information autonomy, recognising it a component of the right to legal protection of private life. (Oniszczuk, 2004, pp. 468-469). Autonomy means the right to independently decide whether to reveal to others the information concerning a particular person, as well as the right to control such information, being in possession of other entities. (U 3/01). The basic rule in this context is an obligation of obtaining the concerned person's consent to share the information. The Constitutional Tribunal also pointed out that the provision of Article 51 of the Constitution of the RP refers to all the cases where the individual is obligated to reveal the information about him/herself to other entities, both the entities of public authorities and private entities. The constitutional responsibility of protection of the sphere of private life imposed by the legislator demands providing the individual with proper protection to an equal degree from intrusion of public and private entities, i.e. in the vertical and horizontal dimension.

In the aspect of information autonomy of the individual the Constitutional Tribunal decided that the infringement of privacy occurs through the obligation of submitting a lustration statement and revealing the fact of 
cooperation with the communist security services. Also the right of Inland Revenue Offices to insight in the taxpayer's bills within the tax proceedings was recognised as intrusion into the sphere of private life, (K 15/98) as well the obligation of providing by councillors the information on their material status, including the information on incomes from employment or other gainful activity or occupation, with providing the sums achieved as the result of each of the titles. (SK 7/05). In the opinion of the Constitutional Tribunal the right to privacy includes the protection of confidentiality of data on the citizen's material situation, including bank accounts (and similar) he/she possesses as well as his/her transactions. (K 21/96). Thus, the Tribunal acknowledged that the revenue and tax organs' control of the bank documentation is an illegal intrusion into citizens' personal lives.

The analysis of the aforementioned judicial decisions of the Constitutional Tribunal indicates that the information on the material situation constitute an element of privacy. (Oniszczuk, 2004, p. 461). The Constitutional Tribunal pointed out that the right to privacy extends over the secret of the citizen's material situation. This also refers to his/her bank accounts and transactions. This concerns in particular the situations where the citizen does not act as a business entity but a private person. (K 21/96). However, data referring to the individual's property and economic sphere, despite the legal guarantees of protection of privacy and providing protection of personal data, are not subject to so rigorous conditions of limitations as the purely personal sphere. (K 41/02).

On the basis of the judicial decisions of the Constitutional Tribunal it is important to state that the Tribunal adopts a wide range of the right to privacy defining this sphere with general terms, unspecified, of the nature of general clauses. Privacy, in accordance with the judicial decisions of the Constitutional Tribunal refers mainly to personal, family and social life. It is also defined with the name of right to be left alone, guaranteeing a certain state of independence, in which the individual may decide on the scope and range of sharing and communicating the information on his/her life to other people. Within privacy the individual has the right to keep in secret the information on his/her private life and protection of the data which concerns him/her. The sphere of private life also includes information on the state of health and the individual's material situation. The Constitutional Tribunal, however, diversifies the range of the granted legal protection depending on the sphere which the violation concerns. Securing the respect for the personal, intimate sphere deserves much more protection that the economic (material) sphere of the individual. 


\section{Premises of the principle of proportionality}

The provision of Article 31 para 3 of the Constitution of the RP as well as the judicial decisions of the Constitutional Tribunal imply the following premises of acceptability of restrictions in exercising the constitutional liberties and rights. They must be met cumulatively for the limitations to be legally acceptable:

1) a statutory form of the limitation;

2) the necessity for introducing limitations in a democratic state, i.e. also lack of other available effective means pursuing a similar end;

3) a functional connection of the limitation with implementing the values outlined in this provision, which are:

a) security of the state,

b) public order,

c) environment protection,

d) health protection,

e) protection of public morality,

f) protection of the rights and liberties of other people;

4) the range of violating the essence of a particular right and liberty. (P 2/98; K 33/02; SK 9/98; Zakolska, 2008, p. 115).

The doctrine emphasises that the first requirement makes a procedural or formal aspect defined as the principle of statutory exclusivity (Eabno, 2002, p. 699), whereas the remaining three premises constitute a material aspect of imposing the restrictions. (Oniszczuk, p. 2004, 392; P 11/98).

\subsection{The requirement of a statutory form of limitations}

The requirement of a statutory form of limiting the individual's rights and liberties stems from the reasons of guarantee. The statute (act of law) is the highest act of ordinary legislation, resolved through an open procedure, which enables the public opinion to follow works on its final form and gives an opportunity to react in the case of an excessive extension of the acceptable restrictions. Moreover, there is a possibility of controlling its constitutionality by the Constitutional Tribunal even before its promulgation. (Wyrzykowski, 1998, p. 48-49). The principle of statutory exclusiveness means an obligation of regulating a particular limitation in an act of law of the statutory weight and preserving the correctness of the legislative procedure. (Garlicki, 2001, p. 10-12; Łabno, 2002, p. 701 and next). The Constitutional Tribunal pointed out that what is subject to examination is the circumstance if the act came into effect in compliance with the procedure required by provisions of law to pass it. Finding the procedure required 
to proper passing the act violated results in incompliance of the questioned regulation and the whole act with the Constitution of the RP. (K 3/98).

The requirement of a statutory form of limitations also contains a proposition of clearness and completeness of an act as well as proper legislation. ${ }^{3}$ In accordance with the judicial decisions of the Constitutional Tribunal the reservation of a statutory form of limitations in Article 31 para 3 of the Constitution of the RP means a prohibition of sub delegation or transferring the regulatory (legislative) competence to another body, or regulating a particular matter in a legal document inferior to a statute (act of law). (U 5/97; U 3/01). Simultaneously, however, the term 'statutory form of limitation of rights and liberties' is also understood by the Constitutional Tribunal as a situation, where the act of law (statute) forms only basic forms of limitations, whose development and completion may occur in an inferior legal document. (Banaszak, 2009, p. 176; Wojtyczek, 1999, p. 110). The Constitutional Tribunal emphasised that the due correctness, precision and clarity of legal regulations is of particular importance for protecting constitutional liberties and rights of human and the citizen. (K 39/97). The regulation authorising intrusion into the sphere of civil rights and liberties must meet the requirement of satisfactory definiteness, which results from the principles of the certainty of law and citizens' trust in the state, which are based on the clause of democratic state ruled by law. (Działocha, Zalasiński, 2009, p. 4). The very crossing of a certain level of unclearness of legal regulations may become a sufficient premise to state their incompliance with the Constitution of the RP. Moreover, the statutory regulation must regulate all cases of real importance completely and exhaustively. The Constitutional Tribunal understands this term as a precise determination of the range of the intrusion, as well as the mode in which the entity limited in his/her rights may defend him/herself from the unjustified infringement of his/her personal rights and demand control over the legitimacy of the organ's action. (U 6/92). Considering the case of infringement of the right to privacy the Constitutional Tribunal demonstrated that the legislator granting the state organs competences of invasion in the sphere of privacy should determine the means and the procedure of the protection of this right. The principle of democratic state ruled by law requires it. (K 21/96).

The control of the limitations of the constitutional liberties and rights of the individual in the case of using unspecified (imprecise) phrases is of special importance in reference to the requirement of clarity of an act of law. Unclear edition of the text of regulations results in a threat of leaving the organs which apply them an excessive discretion at establishing in practice the subjective and objective range of the restrictions. (K 33/00). This means 
that it is unacceptable to adopt in an act of law 'blank' regulations, which leave the form and range of limitations at the discretion of the organs of local governments or the executive power. (P 11/98).

\subsection{The requirement of necessity for restrictions}

The requirement of introducing a restriction in a democratic state means a real need for intrusion, in particular circumstances, into the individual's right or liberty. It is about the legal means which are:

- necessary to achieve a particular end,

- indispensable, because using other means fails to achieve the intended end;

- proportional, which means that they are the least burdensome to the entities whose rights and liberties are limited, and simultaneously remain in a rational proportion to the ends the protection of which the limitation justifies. (P. 2/98).

The doctrine underscores that the Constitutional Tribunal relativises the evaluation of meeting particular criteria composing the principle of proportionality depending on the nature of the right or the liberty which the limitation concerns. More severe standards of assessment are applied for regulating personal and political rights and liberties than economic and social rights. (K 10/95; Oniszczuk, 2004, p. 256).

Thus, de facto the premise of necessity contains three principles composing the principle of proportionality:

1) the principle of suitability (indispensability),

2) the principle of necessity and

3) the principle of proportionality in the strict sense. (Wojtyczek, 2002, p. 682; Oniszczuk, 2004, p. 256; P 2/98).

Re. 1: The requirement of suitability imposes verifying if the means applied is useful, adequate and if is suitable for achieving the intended end. The application of the principle of suitability requires from the organs applying law establishing the objective of the act of law under examination. (Wojtyczek, 2002, pp. 682-684).

Re 2: The principle of necessity introduces the requirement of checking if there is another, less burdensome means, which is equally effective in leading to the intended end.

Re 3: The principle of proportionality in the strict sense requires preserving accurate proportions between the positive effect of the particular legal regulation and the burdens imposed upon the individual. (Wojtyczek, 2002 , p. 685). This narrows down to comparing and weighing between the prospective end and its profits on the one hand, and damages suffered and 
reducing other rights on the other. This premise compels preserving an appropriate relation and proportion between the limiting the particular constitutional liberty or right and the intended end of the legal regulation and selecting the means that are the least burdensome and painful. The requirement of proportionality in the strict sense assumes then a necessity of weighing two values which cannot be simultaneously implemented completely through defining their importance. (Wojtyczek, 2002, p. 671). It is just the answer to the question if the so-called "axiological account" speaks in favour of the imposed limitation. In accordance with the principle of proportionality, it is important to pursue the fullest implementation of the rights protected resigning from the full implementation of each of them but in such a way that the limitations in relation to each of these rights were proportional.

The Constitutional Tribunal has emphasised many times that it is not sufficient that the means applied "were conducive to the ends" which should be achieved, "facilitated their achievement" or "were convenient" for the authorities, who are supposed to use them to achieve their ends. The limitations must be justified with the necessity of their introduction. Purposefulness, utility or convenience are not sufficient for imposing limitations (Eętowska, 1998, p. 17), and then the proposal of necessity and proportional in the strict sense is not implemented. (K 41/02; K 4/04).

\subsection{Values justifying restrictions}

Limitations of the constitutional rights and liberties are acceptable for the values presented in Article 31 para 3 of the Constitution of the RP, which construct the notion of public interest. (Garlicki, 2001, pp. 12-13; Zakolska, 2008, p. 127). This notion is composed of six values enumerated in the regulation in question: the need for providing security or public order, environment protection, public health and morality, or liberties and rights of other people. (Banaszak, 2009, p. 177; Wyrzykowski, 1998, p. 50 and next; Garlicki, 2001, p. 14-18; Zakolska, 2008, p. 128-134). All the aforementioned values appertain to the task of the public authorities. The catalogue of these values is closed and it is not possible to interpret it extensively. (K 23/98). However, it is emphasised that the phrases the legislator used forming the values in Article 31 para 3 of the Constitution of the RP are so general that they embrace almost all cases of limitations of the constitutional liberties and rights. (Garlicki, 2001, p. 13). The doctrine expresses an opinion that the legal regulation in point uses generously clauses allowing for limitations, pointing at other premises which refer to the particular liberties and rights guaranteed by the Constitution of the RP. (Wyrzykowski, 1998, p. 52-55). 


\subsection{The prohibition of violating the essence of rights and liberties}

The prohibition of infringing the essence of a particular right and liberty (Wesensgehalt) is expected to prevent excessive intrusion in the content of this law in the way leading to violating its essence and defines the limits of intrusion into the constitutional rights and liberties. In the German doctrine this clause is referred to as Schranken-Schranke, which means limitation of limitations. (Łabno, 2002, p. 700; Garlicki, 2001, p. 6). According to this principle it is believed that there is a certain minimum scope of the substance of each liberty and each right, and depriving a person this minimum equals eliminating a given right. (Łabno, 2002, p. 707). The Constitutional Tribunal emphasised it strongly, stating that the scope of the limitations cannot destroy the basic components of the individual right, resulting in depriving it its real substance and leading to transforming it into a pretence of law. This situation leads to the violation of the essence of law and its basic substance, which on the basis of the Constitution is unacceptable. (K 33/02). The essence of a liberty or a right occurs if legal regulations preclude exercising them, however not lifting them in practice. (Banaszak, 2009, p. 180). The Constitutional Tribunal demonstrated that the prohibition of infringing the essence of rights and liberties should not be reduced just to the negative aspect of this principle, which demands moderating the limitations. It is also important to emphasise the positive aspect through pointing at the essence of every right and liberty. (P 2/98; Łabno, 2002, p. 706-707). It is important to mention that determining this core always occurs in concrete circumstances for an abstract determination of the elements of the substance which guarantee the existence of the particular liberty or right is not possible. (Łabno, 2002, p. 708; Garlicki, 2001, p. 24).

The doctrine points at two ways of understanding the prohibition of violating the essence of liberties and rights:

1) the theory of absolute essence, according to which there exists unchanged, absolute essence of any constitutional liberty and right independent from any particular situation,

2) the theory of relative essence, according to which the notion of the essence of constitutional rights and liberties is relative, determined by particular circumstances of the situation. (Banaszak, 2009, p. 180).

The Constitutional Tribunal acknowledges that the conception of the essence of rights and liberties is based on the assumption that it is possible to extract from any liberty and right its core, a nucleus which determines the existence of such right or liberty as well as additional elements, the 
so-called 'envelope', which may be limited and modified in a different way without detriment to the particular right and liberty. The inviolable core must remain free from the intervention of the legislator even when the aim of the legal regulation introduced is to protect the values pointed at in Article 31 para 3 of the Constitution of the RP. (SK 9/98). The violation of the essence of a right or liberty would occur if the limitations introduced concerned the basic entitlements comprising the substance of the particular right and preclude this right from implementing the function which it is expected to fulfil in the legal order. (P 2/98; Zołotar, 2008).

The judicial decisions of the Constitutional Tribunal emphasise the view that evaluating the proportionality of the imposed limitations in relation to the sacrificed rights, the legislator has to respect the system of ethical values reflected in the Constitution of the RP, and cannot sacrifice more precious values in order to achieve less precious values (K 2/98). Simultaneously the evaluation of meeting particular criteria depends on concrete factual circumstances, and foremost on the nature of the particular rights and liberties planned to be restricted. (Banaszak, 2009, p. 181; K 23/98). Hence the stricter standards of evaluation should be applied to the regulations concerning the so-called "classical" rights and liberties, i.e. personal and political, than to economic and social rights, which by nature are left to the political discretion of legislative regulation. (K 3/98). The Constitutional Tribunal underscored that within certain matters the Constitution of the RP grants the legislator much narrower framework of political discretion of legislative regulation. This refers foremost to standardising the "classical" (personal and political) rights of human and the citizen because the constitutional assumption is to leave maximum freedom to the individual. Any regulations limiting these rights and liberties must refer to particular requirements established especially in Article 31 para 3 of the Constitution of the RP.

\section{The principle of proportionality and the limitations of privacy of people performing public functions}

Considerations on the process of specifying the principle of proportionality in the judicial decisions of the Constitutional Tribunal and its premises allow to evaluate the way and for what values limitations of the right to privacy of people performing public functions occur. The judicial decisions of the Constitutional Tribunal referring to the problems of limiting the privacy of people performing public functions concerned the examination of compli- 
ance with the Constitution of the RP the regulations included in particular in the following acts of law:

1) ustawa $\mathrm{z}$ dnia 11 kwietnia 1997 r. o ujawnieniu pracy lub służby w organach bezpieczeństwa państwa lub współpracy z nimi w latach 1944-1990 osób pełniących funkcje publiczne (D. U. z $1999 \mathrm{Nr} 42$, poz. 428 j.t.).

2) ustawa $\mathrm{z}$ dnia 23 listopada 2002 r. o zmianie ustawy o samorządzie gminnym oraz o zmianie niektórych innych ustaw (Dz. U. z 2002 Nr 214, poz. 1806).

Re 1: The Lustration Act has been a subject of many examinations of the constitutionality of its particular solutions with the Constitution of the RP. (K 24/98; K 39/97; P 3/00; K 11/02; K 7/01; SK 10/99; P 8/02; Zakolska, 2008, pp. 209-214). One of the decisions concerned the very obligation of submitting appropriate statements (so-called lustration statements), which, according to the initiators of the proceedings before the Constitutional Tribunal, a group of deputies, led to the situation of "self-accusation", which is against the rule of "the right to silence" and cannot be in harmony with the principle of social justice. The Constitutional Tribunal decided that the weighing between the aim of the Lustration Act and the right to legal protection of private life speaks in favour of the former, which is a proposal of securing transparency of public life and protection of the interest of the state connected with the correct performing the most important public functions through elimination the threat of blackmailing with the past facts in relation to the people who occupy key decisive positions in the state. (K 39/97; K 7/01; Oniszczuk, 2004, p. 403 and next). The Tribunal emphasised that the limitations of the right to privacy and the right to decide on one's personal life and burdens connected with the obligation of submitting the lustration statement are included in the price of applying for election or nomination for public functions in the state. (Oniszczuk, 2004, p. 404).

The question being the basis of the application to the Constitutional Tribunal for certifying the conformity with the Constitution in the case in point was not evaluated unequivocally. Four judges of the Constitutional Tribunal declared their dissented opinions. Judge Z. Czeszejko-Sochacki argued that the content of the lustration statement concerns the facts in the sphere of private life, which have not been known so far, and admitting to which, on the one hand, may expose the person to social effects (moral, in his/her environment, professional, family), whereas not admitting them to losing the performed public function. Hence the statement is an intrusion into the sphere of private life and a breach of the information autonomy. According to Judge Z. Czeszejko-Sochacki the legislator introducing the 
aforesaid limitation by no means proved that imposing a legal obligation of revealing information is necessary in the democratic state for its security or preserving freedoms and rights of other people. Hence he recognised the questioned solution as not in conformity to the Constitution.

In accordance with the position of the Constitutional Tribunal, the right to privacy is violated by the obligation of submitting the lustration statement itself. However, this finds justification in the ends of lustration and results directly from the will of performing a public function by the particular person. Thus, limiting the right to privacy is justified because of the protection of values in Article 31 para 3 of the Constitution of the RP, which is the security of the state. It is important to note, which the Constitutional Tribunal emphasised, that no citizen is obligated to apply for a public function. Deciding to do so, he/she makes a fully independent and conscious decision, including certain restrictions and discomfort connected with the intrusion into his/her private life. It is commonly assumed that in relation to the people performing public functions, limiting the sphere of their privacy is acceptable.

Re 2: A justified intrusion in the sphere of privacy of people performing public functions cannot lead to infringement of privacy of their family members, who still remain private persons. This is the position taken by the Constitutional Tribunal in the decision of 13 July 2004. (K 20/03). The subject of the examination of constitutionality was the regulation imposing upon local government functionaries an obligation to submit statements - open and published in the Bulletin of Public Information - concerning spouses, ascendants, descendants and siblings on businesses run by these people on the territory of a, respectively, commune, district and province, the functionary of which is the person submitting the statement as well as on civil law agreements these people entered with local government organs. ${ }^{4}$ This regulation lead to violation of the right to privacy of these people, who do not perform public functions. Ipso facto it was against Article 61 para 1 of the Constitution of the RP. The Constitutional Tribunal, confirming the legitimacy of the objective of the regulation, which was, inter alia, combat against corruption, decided that it is not a proper means to achieve it, because the limits resulting from Article 31 para 3 of the Constitution of the RP were exceeded. The effects of the questioned regulations concerned very sensitive and delicate affairs. According to the Constitutional Tribunal, the very revealing of kinship in certain cases may infringe privacy of the functionary and his close person (e.g. in the case of children out of the wedlock, raising a child of whom the functionary is not a parent, half-siblings). Moreover, certain events may lead to an indirect revealing 


\section{Joanna Sieńczyło-Chlabicz, Zofia Zawadzka}

of situations or life plans of the person in point (separation, divorce or an intention of marriage). Also informing about events in the life of the family, publicly connecting accomplishments with the fact of being in family relationships with the functionary may be simply humiliating, if the family members reached certain property or position through their own efforts only. Thus, the fact that in some local government units occur pathologies does not justify imposing upon all functionaries the obligation of informing about important events in their relatives' lives.

The question of the spouse, on the other hand, is different. In the opinion of the Constitutional Tribunal, gaining a profit by the functionary's spouse should be treated almost the same as gaining a profit by the functionary him/herself because in most cases they remain in the statutory joint marital property regime, and even if not, the profits gained are for the spouses' joint use. Hence the obligation, imposed by regulation, of submitting statements and informing on the property situation of the functionary's spouse remains within the limits of the principle of proportionality and by the same token is not inconsistent with the Constitution.

It is important to underscore that the values connected with the transparency of public life lead to considerably narrower outlining the limit of legally protected privacy of people performing public functions in comparison with private people. An intrusion in privacy, however, occurs only when these people decide to perform public functions, which is not obligatory. Transparency of public life in a democratic state sometimes results in revealing information on people performing public functions evoking negative reactions of the public opinion. This is, however, often justified with public interest and protection of the democratic institutions of the state. (K 7/01).

In accordance with the judicial decisions of the Constitutional Tribunal the sphere of the public activity of people performing public functions sometimes overlaps with the sphere of their private life and there is no possibility of strict and clear separation of both these spheres. Privacy of the people of this category may be limited for the openness, transparency and availability of information about the functioning of public institutions in a democratic state. However, this cannot lead to a complete negation of the protection of the sphere of private life. The moment these people begin performing public functions, they have to take into account and accept the broader range of intrusion into the sphere of their privacy. (K 17/05). Simultaneously, the Constitutional Tribunal pointed out that in the situation of a collision or conflict of two values: the civil right to information and the right to privacy, it is not allowed to give priority to the former. We should not guarantee 
citizens access to information at all costs. (K 11/02). Exercising the civil right to information in the case of people performing public functions cannot lead to exclusion of protection of the rights which the Constitution of the RP guarantees everybody. This concerns mainly the right to privacy. (K 41/02). The Constitutional Tribunal emphasised that the range of the right to information definitely does not include information on the intimate sphere, for instance, on the state of health. (K 17/05).

The analysis of the judicial decisions of the Constitutional Tribunal allows us to draw the conclusion that in reference to the information concerning the past of people performing public functions referring to the fact of these people's collaboration with the organs of security, limitations of the right to privacy are acceptable. This information is connected directly with the public functions performed and not revealing it may expose the persons to the danger of blackmail during performing their public tasks. Similarly, it is acceptable to limit privacy of people performing public functions through obliging them and their spouses to submitting the so-called property statements. These limitations are justified on grounds of the openness and transparency of public life as well as the necessity of preventing corruption in the organs of public authorities. However, the obligation of sharing personal and sensitive information, which even indirectly contribute to revealing life plans and family information of personal and delicate nature was recognised as violating the guarantee of legal protection of privacy and as intruding into the essence of this right.

\section{Conclusions}

It is unquestionable that people performing public functions are entitled to much narrower range of privacy protection than the so-called private persons, because of voluntary holding a public office, the right of citizens to public information as well as the necessity of preserving transparency and openness of public life. Thus, the principle of proportionality should refer to foremost needs connected with proper functioning of public institutions, and not only to the status of people performing public functions as citizens. (SK 7/05). However, it is important to underscore that intrusion into privacy of the people of this category should be always justified on grounds of a direct connection between their functioning in the sphere of private life and the function (office) performed for the state and the public good. The Constitutional Tribunal pointed in its judicial decisions at the conditions on the cumulative meeting of which depends the acceptable intrusion into 


\section{Joanna Sieńczyło-Chlabicz, Zofia Zawadzka}

privacy of the so-called public persons. First, the limitations must be justified with the necessity of protection of one of the values listed in Article 31 para 3 of the Constitution of the RP. Secondly, it is indispensable to demonstrate that performing a public function constitutes an adequate criterion of lowering the standard of protection of this person's privacy. (Laskowska, 2008, p. 76).

This means that the information infringing the rights and liberties of the person cannot exceed the absolute necessity or be incommensurate with the value which is the openness and transparency of public life. Otherwise, the requirements of the principle of proportionality in imposing limitations on exercising the constitutional liberties and rights are not met. The information should also be of importance for evaluating the functioning of an institution of a person performing a public function and must be connected with the fact of performing this function. Between the information about the person and the public function performed by this person there should be a functional connection evaluated in concreto. Even a socially important aim, such as combating corruption or preventing political blackmail, cannot lead to eliminating the essence of the right to privacy or to revealing information of intimate and personal nature, concerning the family of a person performing public functions, his/her state of health or sexuality. Moreover, the information cannot intrude into the essence of the right to privacy or, in reality, eliminate the sense of legal protection of private life. The limits of intrusion into the sphere of private life are always outlined with the injunction of respecting personal dignity, and when imposing limitations it is important to take into consideration the fact that the good (right) which is assumed to be pursued and the good "sacrificed" on the basis of the Constitution of the RP are equal values.

\section{N O T E S}

${ }^{1}$ See also wyrok Trybunału Konstytucyjnego z 16 kwietnia 2002 r. (SK 23/01) as well as Judge Andrzej Mączyński's dissented opinion on this decision.

${ }^{2}$ Wyrok Trybunału Konstytucyjnego z dnia 13 lipca 2004 r.: the decision in point was taken on the basis of the evaluation of theconstitutionality of legal solutions introduced to laws on local governments, which imposed upon local government officials an obligation of submitting statements concerning their spouses, their ascendants, descendants and siblings, whose content was to be information on business run by these persons on the territory, respectively, of the commune, the district and the province of which the person submitting the statement is a functionary as well as in civil law agreements between these people and the organs, organisational units or legal persons of, respectively, the commune, the district and the province. (K 20/03). 
The Principle of Proportionality as a Method of Limiting the Privacy...

${ }^{3}$ For more see the judicial decisions of the Constitutional Tribunal cited by Koźmiński, A. K. (2008). Wolności, prawa i obowiązki człowieka i obywatela. In M. Zubik (Ed.), Konstytucja III RP w tezach orzeczniczych Trybunatu Konstytucyjnego i wybranych sądów (pp. 171-174). Warszawa: C.H. Beck.

4 This regulation was introduced by the Act of 23 November 2002 (Dz.U. Nr 214, poz. 1806) on amending the Act on Commune Local Government and on amending certain other acta.

\section{R E F E R E N C E S}

Banaszak, B. (2009). Konstytucja Rzeczypospolitej Polskiej. Komentarz. Warszawa: C.H. Beck, 181.

Dylewska, J. (2001). Zasada proporcjonalności w orzecznictwie Trybunału Konstytucyjnego po wejściu w życie Konstytucji RP z 2 kwietnia 1997 r. Przeglad Sejmowy, 1, 47 and next.

Działocha, K., Zalasiński, T. (2009). "Określoność" przepisów prawa jako przedmiot kontroli konstytucyjności prawa w poglądach Trybunału Konstytucyjnego. In S. Bożyk (Ed.), Prawo, parlament $i$ egzekutywa we wspótczesnych systemach rzadów. Księga poświęcona pamięci Profesora Jerzego Stembrowicza (p. 43). Białystok: Temida 2.

Gardocka T. (Ed.), Obywatelskie prawo do informacji (p. 76). Warszawa: Wolters Kluwer.

Garlicki, L. (2001), Przesłanki ograniczania konstytucyjnych praw i wolności (na tle orzecznictwa Trybunału Konstytucyjnego). Państwo i Prawo, 10, 10-12.

Konstytucja Polskiej Rzeczypospolitej Ludowej (Dz. U. z 1952 Nr 33, poz. 232 z późn. zm.).

Konstytucja Polskiej Rzeczypospolitej Ludowej uchwalona przez Sejm Ustawodawczy w dniu 22 lipca 1952 r. (Dz.U. z $1976 \mathrm{Nr}$ 7, poz. 36 j.t.).

Konstytucja Rzeczypospolitej Polskiej z dnia 2 kwietnia 1997 r. (Dz. U. z 1997 Nr 78, poz. 483).

Koźmiński, A.K. (2008). Wolności, prawa i obowiązki człowieka i obywatela. In M. Zubik (Ed.), Konstytucja III RP w tezach orzeczniczych Trybunatu Konstytucyjnego i wybranych sqdów (pp. 171-174). Warszawa: C.H. Beck.

Laskowska, M. (2008). Prawo do informacji o działalności osób pełniących funkcje publiczne a ich prawo do ochrony prawnej życia prywatnego. Refleksje na tle orzecznictwa TK. In T. Gardocka (Ed.), Obywatelskie prawo do informacji, (p. 76). Warszawa: Wolters Kluwer.

Łabno, A. (2002). Ograniczenie wolności i praw człowieka na podstawie art. 31 Konstytucji III RP. In B. Banaszak \& A. Preisner (Eds.), Prawa i wolności obywatelskie w Konstytucji RP (p. 704). Warszawa: C.H. Beck. 
Joanna Sieńczyło-Chlabicz, Zofia Zawadzka

Łętowska, E. (1998) Ochrona praw jednostki w polskiej Konstytucji z 1997 r. In Szkoła Praw Człowieka. Teksty wykładów, z. 2 (p. 17). Warszawa: Helsińska Fundacja Praw Człowieka, 17.

Martins, L. (2001). Die Grundrechtskollision. Grundrechtskonkretisierung am Beispiel des $§ 41$ Abs. 1 BDSG. Berlin, 120.

Oniszczuk, J. (2000). Konstytucja Rzeczypospolitej Polskiej w orzeczeniach Trybunatu Konstytucyjnego. Kraków: Wydawnictwo Zakamycze, 264.

Oniszczuk, J. (2004). Konstytucja Rzeczypospolitej Polskiej w orzecznictwie Trybunatu Konstytucyjnego na poczatku XXI w. Kraków: Zakamycze, 398-399.

Orzeczenie Trybunału Konstytucyjnego z 24 czerwca 1997 r., K 21/96, OTK 1997, nr 2, poz. 33.

Orzeczenie Trybunału Konstytucyjnego z 25 lutego 1999 r., K 23/98, OTK-A 1999, nr 2, poz. 25.

Orzeczenie Trybunału Konstytucyjnego z dnia 16 maja 1995 r., sygn. K 12/93, OTK 1995, nr 1, poz. 14.

Orzeczenie Trybunału Konstytucyjnego z dnia 17 października 1995 r., K 10/95, OTK 1995, nr 2, poz. 10.

Orzeczenie Trybunału Konstytucyjnego z dnia 19 czerwca 1992 r., OTK 1992, nr 1, poz. 13.

Orzeczenie Trybunału Konstytucyjnego z dnia 24 czerwca 1997 r., K 21/96, OTK 1997, nr 2, poz. 33.

Orzeczenie Trybunału Konstytucyjnego z dnia 24 czerwca 1997 r., K 21/96, OTK 1997, nr 2, poz. 23.

Orzeczenie Trybunału Konstytucyjnego z dnia 26 kwietnia 1995 r., K 11/94, OTK 1995, nr 1, poz. 12.

Orzeczenie Trybunału Konstytucyjnego z dnia 26 stycznia 1993 r., U 10/92, OTK 1993, nr 1, poz. 2.

Postanowienie Trybunału Konstytucyjnego z dnia 1 października 2002 r., P 8/02, OTK-A 2002, nr 5, poz. 70.

Postanowienie Trybunału Konstytucyjnego z dnia 4 grudnia 2000 r., SK 10/99, OTK 2000, nr 8, poz. 300.

Safjan, M. (2002). Refleksje wokół konstytucyjnych uwarunkowań rozwoju ochrony dóbr osobistych. KPP, 1, 232.

Sieńczyło-Chlabicz, J. (2006). Naruszenie prywatności osób publicznych przez prasę. Analiza cywilnoprawna. Kraków: Wolters Kluwer, 102.

Stelzer, M. (1991). Das Wesensgehaltargument und der Grundsatz der Verhältnismäßigkeit (= Forschungen aus Staat und Recht). Wien-New York: Springer Verlag, 96.

Stępkowski, A. (2010). Zasada proporcjonalności w europejskiej kulturze prawnej. Sadowa kontrola wtadzy dyskrecjonalnej w nowoczesnej Europie. Warszawa: Liber, 327-348. 
The Principle of Proportionality as a Method of Limiting the Privacy...

Uchwała Trybunału Konstytucyjnego z dnia 2 marca 1994 r., W3/93, OTK, 1994, nr 1, poz. 17.

Ustawa konstytucyjna z dnia 17 października 1992 r. o wzajemnych stosunkach między władzą ustawodawczą i wykonawczą Rzeczypospolitej Polskiej oraz o samorządzie terytorialnym (Dz.U. 1992 Nr 84 poz. 426 z późn. zm.).

Walaszek-Pyzioł, A. (1995) Zasada proporcjonalności w orzecznictwie Trybunału Konstytucyjnego. Przeglad Ustawodawstwa Gospodarczego, 1, 5.

Wojtyczek, K. (1999). Granice ingerencji ustawodawczej w sfere praw człowieka w Konstytucji RP. Kraków: Zakamycze, 110.

Wojtyczek, K. (2002) Zasada proporcjonalności. In B. Banaszak \& A. Preisner (Eds.), Prawa i wolności obywatelskie w Konstytucji RP (p. 679). Warszawa: C.H. Beck.

Wyrok Trybunału Konstytucyjnego z 16 kwietnia 2002 r. SK 23/01, OTK-A 2002, nr 3, poz. 26.

Wyrok Trybunału Konstytucyjnego z dnia 10 listopada 1998 r., K 39/97, OTK 1998, nr 6, poz. 99.

Wyrok Trybunału Konstytucyjnego z dnia 11 kwietnia 2000 r., K 15/98, OTK 2000, nr 3, poz. 86.

Wyrok Trybunału Konstytucyjnego z dnia 12 stycznia 1999 r., P 2/98, OTK 1999, nr 1, poz. 2.

Wyrok Trybunału Konstytucyjnego z dnia 12 stycznia 2000 r., P. 11/98, (Dz.U. z $2000 \mathrm{nr} 3$, poz. 46).

Wyrok Trybunału Konstytucyjnego z dnia 13 lipca 2004 r., K 20/03, OTK-A 2004, nr 7,63 .

Wyrok Trybunału Konstytucyjnego z dnia 14 czerwca 2000 r., P 3/00, OTK 2000, nr 5, poz. 138 .

Wyrok Trybunału Konstytucyjnego z dnia 19 czerwca 2002 r., K 11/02, OTK-A 2002, nr 4, poz. 43.

Wyrok Trybunału Konstytucyjnego z dnia 19 grudnia 2002 r., K 33/02, OTK-A 2002, nr 7, poz. 97.

Wyrok Trybunału Konstytucyjnego z dnia 19 lutego 2002, U 3/01, OTK-A, 2002, nr 1, poz. 3 .

Wyrok Trybunału Konstytucyjnego z dnia 19 maja 1998 r., U 5/97, OTK 1998, nr 4, poz. 46 .

Wyrok Trybunału Konstytucyjnego z dnia 20 czerwca 2005 r., K 4/04, OTK-A 2005, nr 6, poz. 64 .

Wyrok Trybunału Konstytucyjnego z dnia 20 listopada 2002 r., K 41/02, OTK-A 2002, nr 6, poz. 83.

Wyrok Trybunału Konstytucyjnego z dnia 20 marca 2006 r., K 17/05, OTK-A 2006, nr 3, poz. 30. 


\section{Joanna Sieńczyło-Chlabicz, Zofia Zawadzka}

Wyrok Trybunału Konstytucyjnego z dnia 21 października 1998 r., K 24/98, OTK 1998, nr 6, poz. 97.

Wyrok Trybunału Konstytucyjnego z dnia 23 marca 1999 r., K 2/98, OTK 1999, nr 3, poz. 38 .

Wyrok Trybunału Konstytucyjnego z dnia 24 czerwca 1998 r., K 3/98, OTK 1998, nr 4, poz. 52 .

Wyrok Trybunału Konstytucyjnego z dnia 25 maja 1999 r., SK 9/98, OTK 1999, nr 4 , poz. 78 .

Wyrok Trybunału Konstytucyjnego z dnia 26 kwietnia 1999 r., K 33/98, OTK 1999, nr 4, poz. 71 .

Wyrok Trybunału Konstytucyjnego z dnia 27 stycznia 1999 r., K 1/98 (Dz. U. z 1999 Nr 20, poz. 180).

Wyrok Trybunału Konstytucyjnego z dnia 29 stycznia 2002 r., K 19/01, OTK-A 2002, nr 1, poz. 1 .

Wyrok Trybunału Konstytucyjnego z dnia 30 października 2001 r., K 33/00, OTK 2001, nr 7, poz. 217.

Wyrok Trybunału Konstytucyjnego z dnia 5 marca 2003 r., K 7/01, OTK-A 2003, nr 3, poz. 19.

Wyrok Trybunału Konstytucyjnego z dnia 6 grudnia 2005 r., SK 7/05, OTK-A 2005, nr 11, poz. 129.

Wyrzykowski, M. (1998). Granice praw i wolności - granice władzy. In B. Radzikowska (Ed.), Obywatel - jego wolności i prawa. Zbiór studiów przygotowanych z okazji 10. lecia urzędu Rzecznika Praw Obywatelskich, (p. 48). Warszawa: Biuro Rzecznika Praw Obywatelskich.

Zakolska, J. (2008). Zasada proporcjonalności w orzecznictwie Trybunału Konstytucyjnego. Warszawa: Wydawnictwo Sejmowe, 32-68.

Zołotar, A. (2008). Zasada proporcjonalności. In M. Zubik (Ed.), Konstytucja III RP w tezach orzeczniczych Trybunatu Konstytucyjnego $i$ wybranych sadów. Warszawa: C.H. Beck. 